\title{
The Relationship Between Emotional Intelligence and The Cognitive Study Results of Class X Student Of Kinematics Materials At Sma Negeri In District Bangko
}

\author{
Hilda Maulida ${ }^{1}$, Menza Hendri ${ }^{2}$, Nova Susanti ${ }^{3}$ \\ ${ }^{1,2,3}$ Physics Education PMIPA FKIP Universitas Jambi, Indonesia \\ Corresponding Author. Email: hildamaulida_reg04@gmail.com
}

\section{Keywords:}

emotional intelligence, the study results

\begin{abstract}
This research was motivated by many people who argued that to achieve high achievement in learning, a person must have a high Intelligence Quotient (IQ) because it is a potential provision that will facilitate learning and will result in optimal learning achievement. According to Binet in Winkel (2009), the essence of intelligence is the ability to set and maintain a goal, to make adjustments to achieve that goal, and to evaluate one's condition critically and objectively. However, according to the results of research in the field of psychology, it proves that IQ is not the only factor that affects a person's learning achievement. Many other factors influence a person's learning achievement and one of them is emotional intelligence. The purpose of this study was to determine whether there is a relationship between emotional intelligence and learning outcomes of physics in class X SMA in District Bangko. This research was a descriptive quantitative correlational study. The independent variable in this study was emotional intelligence while learning outcomes were the dependent variable. Questionnaires that consisted of managing one's emotions, motivating oneself, recognizing other people's emotions or empathy, and building relationships (cooperation) with others were used to collect the data. Learning outcome test questions which consisted of measurement material, vectors, motion, and circular motion were used to measure student learning outcomes. The data analysis technique used SPSS 16.0. by testing the normality of the hypothesis, the significance, and the regression equation. The results of the data analysis showed that the coefficient value of the correlation between emotional intelligence and learning outcomes was $0.356 .0 .356<0.5$ or close to zero means that there is a weak correlation between emotional intelligence and learning outcomes. To test the hypothesis, it was obtained tcount> t table or 12.042> 1.977 then $\mathrm{H} 0$ is rejected. It can be said that there is a significant correlation between emotional intelligence and physics learning outcomes of class X students at SMA Negeri in District Bangko.
\end{abstract}

C2020 JSER. Yogyakarta State University

\section{INTRODUCTION}

Education is a conscious and planned effort to create a learning atmosphere and process. The goal is for students to actively develop their potential. Furthermore, students can have religious-spiritual strength, self-control, personality, intelligence, noble morals, and skills needed for themselves, society, nation, and the state (UUSPN No. 20 of 2003).

The learning process at school is complex and comprehensive. Many people argue that to achieve high achievement in learning, a person must have a high Intelligence Quotient (IQ) because intelligence 
is a potential provision that will facilitate learning and in turn, will result in optimal learning achievement.

Binet in Winkel (2010) states that the essence of intelligence is the ability to set and maintain a goal, to make adjustments to achieve that goal, and to assess the condition of oneself critically and objectively.

According to Goleman (2015), intellectual intelligence (IQ) only contributes $20 \%$ to success, while $80 \%$ is the contribution of other strengths, including emotional intelligence or Emotional Quotient (EQ), namely the ability to motivate yourself, overcome frustration, control heart pressure, set the mood, empathy, and the ability to work together.

EQ always precedes rational intelligence. Good EQ can determine student success in achievement. Goleman (2015) states that emotional intelligence is the ability of a person to manage our emotional life with intelligence and to maintain emotional harmony and expression (the appropriateness of emotion and its expression). It occurs through selfawareness skills, self-control, self-motivation, empathy, and social skills. According to Goleman (2015), people who have high academic intelligence tend to have unreasonable anxiety, are too critical and fussy, tend to withdraw, seem cold, tend to find it difficult to express resentment and anger unreasonably. This is supported by a low level of emotional intelligence. Because of the above characteristics, if a person has a high IQ but a low level of emotional intelligence, they tend to be seen as stubborn, difficult to socialize, easily frustrated, not easy to trust others, not sensitive to the condition of environment and tend to give up when experiencing stress.

Based on the background of the problems described above, the problem is whether there is a significant relationship between emotional intelligence and cognitive learning outcomes of class X students on Kinematics material at SMA Negeri in District Bangko in the odd semester of the $2015 / 2016$ academic year. This study aims to determine whether there is a significant relationship between emotional intelligence and cognitive learning outcomes of class $\mathrm{X}$ students on Kinematics material at SMA Negeri in District Bangko. The results of this study are expected to be useful for teachers, students, and researchers. It can give a contribution of thoughts for teachers in the field of physics lessons in understanding the problem of emotional intelligence in physics lessons, especially in improving the quality of student physics learning outcomes in schools so that they can achieve goals more optimally. Meanwhile, students will understand the level of emotional intelligence they have so that they can recognize their feelings, feelings, and emotions of others, and be able to motivate themselves. For researchers, this study can be a requirement to complete a Bachelor's degree in Physics Education at Jambi University.

Because the scope of this research was very broad, the author limited the sample to be studied was the State Senior High School in District Bangko Jambi in the odd semester of the 2015/2016 academic year. In this study, the learning outcomes seen were students' physics learning outcomes in cognitive aspects only, and the learning materials tested were measurement, vector addition, straight motion, and circular motion. The operational definition of variables were divided into emotional intelligence and learning outcomes. Emotional intelligence is intelligence that can identify or manage and control one's emotions and the ability to understand the condition of others. Learning outcomes are the level of a person's success in studying subject matter at school which is expressed in the form of scores obtained from test results regarding several subject matters.

\section{RESEARCH METHOD}

This research was a descriptive quantitative correlational study. Quantitative descriptive research is research that is intended to investigate circumstances, conditions, or other matters. The data obtained is in the form of numbers which are analyzed using statistics. The research was conducted in SMA throughout Bangko District which consisted of two public high schools namely SMA Negeri 1 Merangin and SMA Negeri 7 Merangin in the 2015/2016 academic year.

A variable is a concept that has a variation in the value or logical grouping of two or more attributes. In this study, there were only two variables i.e. students' emotional intelligence as the independent variable $(\mathrm{X})$ and student learning outcomes as the dependent variable (Y). The population is a generalization area consisting of objects/subjects that have certain qualities and characteristics that are determined by the researcher for the study and then draw conclusions. In this study, the population was class X SMA in District Bangko amounting to 318 students. The sample is part of the population that can represent the population. If the population is large and the researcher does not allow studying everything in the population due to limited funds, energy and time, the researcher can use a sample of data taken from that population (Sugiyono, 2011). Then, the researcher took a sample of 147 remaining samples with a random sampling technique.

Data collection techniques applied were emotional intelligence questionnaires and learning outcomes test questions on kinematics metrics covering the materials of quantities and units, 
Hilda Maulida, Menza Hendri, Nova Susanti/ JSER 2020, 4(1), 30

vectors, and motion. At this stage, the calculation of the data obtained used quantitative analysis techniques by performing a normality test using the one-sample Kolmogorov-Smirnov formula with the SPSS 16.0 program. Meanwhile, the hypothesis was tested using the Product Moment Correlation formula.

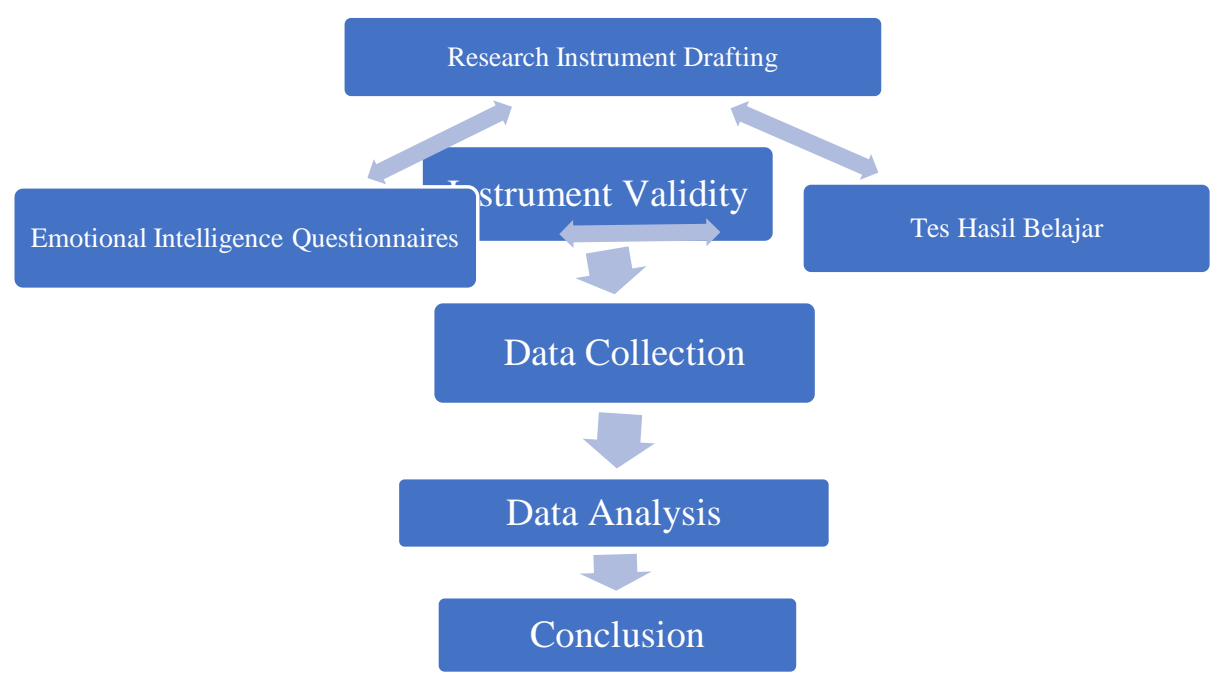

Picture 1. Research Procedures

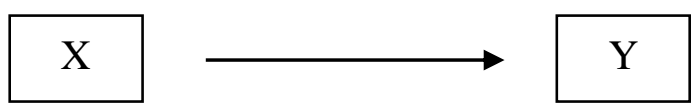

Picture 2. Simple Paradigm. Source: Sugiyono, 2011

\section{RESULTS AND DISCUUSION}

The data obtained from 147 samples showed that 74 students had excellent emotional intelligence, 65 students had good emotional intelligence, and 8 students had less emotional intelligence. In the form of a percentage, it can be seen that $50.43 \%$ had very good emotional intelligence, $44.22 \%$ had good emotional intelligence, and $5.43 \%$ had less emotional intelligence. It can be concluded that the students of class X SMA Negeri District Bangko on average have good emotional intelligence. The following is the percentage of learning outcomes obtained:

Table 1. The percentage of learning outcomes

\begin{tabular}{lcc}
\hline Category & Percentage & Number of Students \\
\hline Very Poor & $7,74 \%$ & 11 \\
Poor & $1,36 \%$ & 2 \\
Fair & $2,04 \%$ & 3 \\
Good & $61,22 \%$ & 90 \\
Excellent & $27,89 \%$ & 41 \\
\hline \multicolumn{2}{c}{ Total } & 147 \\
\hline
\end{tabular}

From the score of student learning outcomes, it can be categorized that students have good learning outcomes. After obtaining questionnaire scores and student learning outcomes tests, both the emotional intelligence questionnaire scores and the learning outcomes were analyzed using Pearson correlation analysis to answer the research hypothesis i.e. whether there is a significant relationship between emotional intelligence and student learning outcomes in the materials of measurement, vectors, 
and motions. From the results of data analysis using SPSS 16.0, the correlation $\mathrm{t}$ result is 0.356 . Hypothesis testing using tcount obtained results of 12.042 and $t$ table from table $t$ of 1.665 . Because tcount was bigger than ttable, $\mathrm{H} 0$ is rejected. It means that there is a significant relationship between emotional intelligence and learning outcomes.

The research results showed that emotional intelligence had a significant relationship with learning outcomes obtained by students. Therefore, it would be better if in delivering learning materials, the teacher pays attention to the emotional intelligence possessed by each student. This is in line with Hidayati's (2015) opinion which states that students must have good emotions and good selfmanagement to be able to control themselves in learning. Students should also have a leadership spirit because it can increase their motivation to move forward and be able to achieve success in academic and social fields. It is important since there is high motivation and curiosity in selfmanagement to improve learning outcomes at school.

Khairunnisa (2013) states that emotional intelligence is also a determining factor for one's achievement. The teacher as an educator is one of the carriers of change who is very instrumental in the learning process in schools. In learning, a teacher must be able to see students' emotional intelligence which includes the way they recognize their own emotions, manage them, motivate, get to know other people, and build good relationships with others.

The condition can be achieved by providing a conducive environment, creating a democratic learning climate, developing empathy, feeling what students feel, involving students optimally in learning, both physically, socially, and emotionally, etc. The poorly managed condition also easily causes other students to be sometimes very eager to agree with something, but in a short time, they turn to reject it. It might mess up the cooperation agreed with other friends. Therefore, the cooperation that has been done tends to fail.

On the other hand, some people whose IQ's are not high because of their persistence and balanced emotions are successful in studying and working. People who have high emotional intelligence will strive to create a balance between themselves and their environment and attempt for pursuing happiness from within themselves, can change something bad for the better, and can work together with other people who have various backgrounds.

This means that emotionally intelligent people will be able to display their social abilities. In other words, someone's emotional intelligence can be seen from the behaviors they show. This assumption is clarified by the opinion of Suparno (2004) in Khairunisa (2013) which explains that a person's intelligence is not only theoretical but must be proven in real terms in everyday life.

\section{CONCLUSIONS}

By testing the hypothesis using the moment product correlation and looking at the relationship between the independent variable and the dependent variable, the $\mathrm{t}$-count value is $\mathbf{1 2 . 0 4 2}$ and the $\mathrm{t}$-table value is 1.977 . Because tcount is bigger than $t$ table (12.042> 1.977) then $\mathrm{H} 0$ is rejected with a significance level of $\alpha=5 \%$. The coefficient value obtained from the results using SPSS.16 reached a value of 0.356 . In this case, this value is included in the weak correlation category. In other words, there is a weak correlation between emotional intelligence and learning outcomes. Meanwhile, the SPSS results showed that there is a significant relationship between emotional intelligence and the learning outcomes of class $X$ students at SMA Negeri in District Bangko.

\section{Suggestions}

Based on the results of research on the relationships between emotional intelligence and learning outcomes of class X students in District Bangko, some recommendations can be given to the students, teachers, and further researchers. It is hoped that grade X SMA students in District Bangko can identify themselves, self-emotion, motivation, social skills. Therefore, by controlling themselves, they can increase self-motivation and accept lessons well, understand the learning materials, and optimize learning outcomes.

Meanwhile, physics teachers can pay more attention to the emotional aspects of students in the learning process, so that it can stimulate students to learn optimally and can help develop aspects of students' emotional intelligence such as selfawareness, self-regulation of empathy and social skills. For further researchers, this study has many limitations, such as in collecting data on learning outcomes. It is preferable to use all subjects so that the results obtained are complex learning achievements. Research samples are multiplied so that the results obtained are truly representative. Besides, the variables used can be reproduced by using other intelligence.

\section{REFERENCES}

Agustian, A. G. 2007. Rahasia Sukses Membangun Kecerdasan Emosi dan Spiritual ESQ: Emotional Spiritual Quotient Berdasarkan 6 Rukun Iman dan 5 Rukun Islam. Jakarta: ARGA Publishing 
Hilda Maulida, Menza Hendri, Nova Susanti/ JSER 2020, 4(1), 32

Anonim.2010.http://www.kemenag.go.id/file/doku men/UU2003.pdf.Diakses pada 5 September 2015

Anonim, 2010.statistik Dikutip dari: http://www.uic.edu/classes/.Diakses Pada Tanggal 5 Oktober 2015. Aunurrahman, 2009. Belajar dan Pembelajaran. Bandung : Alfabeta.

Arikunto, suharsimi, 2010. Prosedur Penelitian suatu Pendekatan Praktik. Jakarta: Rineka Cipta.

Hidayati, Laily. 2012.Hasil Belajar Fisika Siswa Ditinjau Dari Kecerdasan Emosional. Jakarta:UniversitasMuhammadiyah Metro. Dikutip dari http://aresearch.upi.edu/operator/upload/s_p ea 054388 bibliography.pdf.pada tanggal 10 November 2015

Khairunnisa.2013.Pentingnya Kecerdasan Emosional Dalam

Pembelajaran. http:/bdkbanjarmasin.kemenag.go.id/index. php/artikel\&idannisa002. Diakses pada 14 september 2015

Goleman, Daniel. 2015. Kecerdasan Emosional. Jakarta : Gramedia

Sugiyono. 2011. Metode Penelitian Kuantitatif, Kualitatif dan $R \& D$. Bandung : Alfabeta

Nuramin. 2012. Proses Pembelajaran. Jakarta: Pelita Aksara

Purwanto. 2010. Evaluasi Hasil Belajar. Yojgakarta: Pustaka Belajar

Ridwan. 2012. Belajar Mudah Penelitian untuk GuruKaryawan dan Peneliti Pemula. Bandung: Alfabeta.

Winkel,WS. 2010. Psikologi Pendidikan dan Evaluasi Belajar. Jakarta: Gramedia 